\title{
Origin of arsenic and other heavy metals in the rivers of Nepal
}

\author{
*Steven H. Emerman ${ }^{1}$, Tara N. Bhattarai ${ }^{2}$, Danda P. Adhikari ${ }^{2}$, \\ Sunendra R. Joshi ${ }^{2}$, Siddhi L. Lakhe ${ }^{2}$, Aimee J. Luhrs ${ }^{1}$, \\ Kangada R. Prasai ${ }^{3}$, and Kristine L. Robson ${ }^{1}$ \\ ${ }^{1}$ Department of Biology and Environmental Science, Simpson College, Indianola, Iowa 50125, U.S.A. \\ ${ }^{2}$ Department of Geology, Tri-Chandra Campus, Tribhuvan University, Ghantaghar, Kathmandu, Nepal \\ ${ }^{3}$ Central Department of Geology, Tribhuvan University, Kirtipur, Kathmandu, Nepal
}

(*Email:SHEmerman@crosspaths.net)

\begin{abstract}
The objective of this study was to determine which geological zones are contributing As and other heavy metals to the rivers of Nepal. The objective was carried out by measuring concentrations of $\mathrm{As}, \mathrm{Fe}, \mathrm{Co}, \mathrm{Cu}$, and $\mathrm{Zn}$ in rivers dissecting highgrade metamorphic Higher Himalayan rocks of the Khumbu region and comparing them with previously collected data from other geological zones. Concentrations were measured using portable colorimeters and the Hach As test kit in 153 samples collected from 108 locations over two years. For the Khumbu region, $<1 \%$ of samples had As concentrations meeting or exceeding the WHO standard of $10 \mathrm{mcg} / \mathrm{l}$, while $53 \%$ of samples from other geological zones had As $\geq 10 \mu \mathrm{g} / \mathrm{l}$. This result is consistent with the typical low As concentration of schists and gneisses. The elevated levels of fluvial As are not predicted by any of the proposed mechanisms for release of As into groundwater in the Terai region. This suggests that the kinetics of the proposed mechanisms is too slow and, at least in terms of As, the groundwater chemistry is a rough reflection of the surface water chemistry. The suggestion could be tested by measuring groundwater $\mathrm{Co}, \mathrm{Ni}$, and $\mathrm{Cu}$ in the Terai since almost all rivers in Nepal have elevated levels of those heavy metals. Rivers in the Khumbu region that are fed by glacial meltwater have significantly more $\mathrm{Fe}$ and $\mathrm{Co}$ than rivers fed by springs or snowmelt, suggesting that unmapped deposits of $\mathrm{Fe}$ and $\mathrm{Co}$ exist in the Tibetan-Tethyan Zone.
\end{abstract}

\section{INTRODUCTION}

Much attention has been focused recently on the problem of As contamination of groundwater in West Bengal and Bangladesh (Bhattacharya et al. 1997; Dhar et al. 1997; Nickson et al. 1998). It is generally agreed that As contamination is too widespread to be due to human activities such as smelting or use of As-based pesticides (Aswathanarayana 1997). Nickson et al. (1998) and Acharyya et al. $(1999,2000)$ have discussed possible natural sources of As in As-bearing rock units of India and Bangladesh (Bhattacharyya 1972; Das 1977; Ghosh and De 1995). Acharyya et al. (2000) suggested also that the ultimate bedrock source of As may lie in the upper reaches of the Ganges River system. On the other hand, in a comprehensive review of the occurrence of As in natural waters, Smedley and Kinniburgh (2002) wrote with regard to the As-bearing sediments in south Asia, "These sediments are derived from the drainage systems of 3 major rivers (Ganges, Brahmaputra and Meghna) which are themselves sourced from a wide area of the Himalaya. Therefore, while it could be argued that the source of much of the As in the Bengal Basin sediments is derived from specific mineralised areas in the source region, these are likely to be so widespread as to be academic and of little practical relevance."
Arsenic contamination in groundwater is also known to occur in the Terai region of Nepal (Neku and Tandukar 2002; Bhattacharya et al. 2003; Brikowski et al. 2004; Emerman 2004; Shrestha et al. 2004; Kanel et al. 2005; Tandukar et al. 2005). As of January 2004, 18,635 wells had been tested, of which $23.7 \%$ exceeded the World Health Organisation (WHO) guideline value of $10 \mu \mathrm{g} / \mathrm{l}$, while $7.4 \%$ exceeded the Interim Nepal Standard of $50 \mu \mathrm{g} / \mathrm{l}$ (ENPHO and USGS 2004). The Terai region is much closer to possible Himalayan As-bearing source rocks than are West Bengal and Bangladesh. Therefore, it is much more likely that it is possible to identify the sources of As mineralisation that affect the Terai region than other parts of south Asia.

Emerman (2005) chose 17 rivers throughout central Nepal and eight rivers in Kathmandu that drain into the Terai region (Fig. 1), sampled them six times monthly in 2003, and measured the $\mathrm{pH}$ and As concentration. He also measured the concentrations of $\mathrm{Fe}, \mathrm{Co}, \mathrm{Ni}, \mathrm{Cu}$ and $\mathrm{Zn}$, because they are the elements most commonly associated with As (Boyle and Jonasson 1973). Emerman (2005) reached the following conclusions:

(1) Central Nepal does not contain one geographicallylimited source of As in that nearly all rivers showed elevated levels of As. 
(2) Nearly all rivers also showed elevated levels of $\mathrm{Cu}$, $\mathrm{Co}, \mathrm{Fe}$ and $\mathrm{Ni}$, while fluvial $\mathrm{Zn}$ was very close to the global background level. Therefore, As mineralisation may be associated with mineralisation of $\mathrm{Cu}, \mathrm{Co}, \mathrm{Fe}$ or $\mathrm{Ni}$, but probably not with $\mathrm{Zn}$ mineralisation.

(3) Elevated levels of fluvial $\mathrm{Co}, \mathrm{Ni}, \mathrm{Cu}$ and $\mathrm{As}$ in the heavily polluted Kathmandu valley are naturally occurring, but elevated levels of fluvial Fe are not naturally occurring.

Although Emerman (2005) showed that fluvial As did not derive from a limited number of watersheds, he left unanswered the question as to whether fluvial As originated from a particular geological zone. Nepal can be divided into six geological zones (Stöcklin 1980; DMG 1994; Dahal 2006), which are (Fig. 1)

(1) Terai Zone, consisting of Quaternary alluvial sediments,

(2) Siwalik Group, consisting largely of Neogene clastic sedimentary rocks,

(3) Lesser Himalayan Zone, consisting largely of Precambrian to early Palaeozoic carbonate rocks and lowgrade metamorphic rocks,

(4) Higher Himalayan Zone, consisting largely of Precambrian high-grade metamorphic rocks,
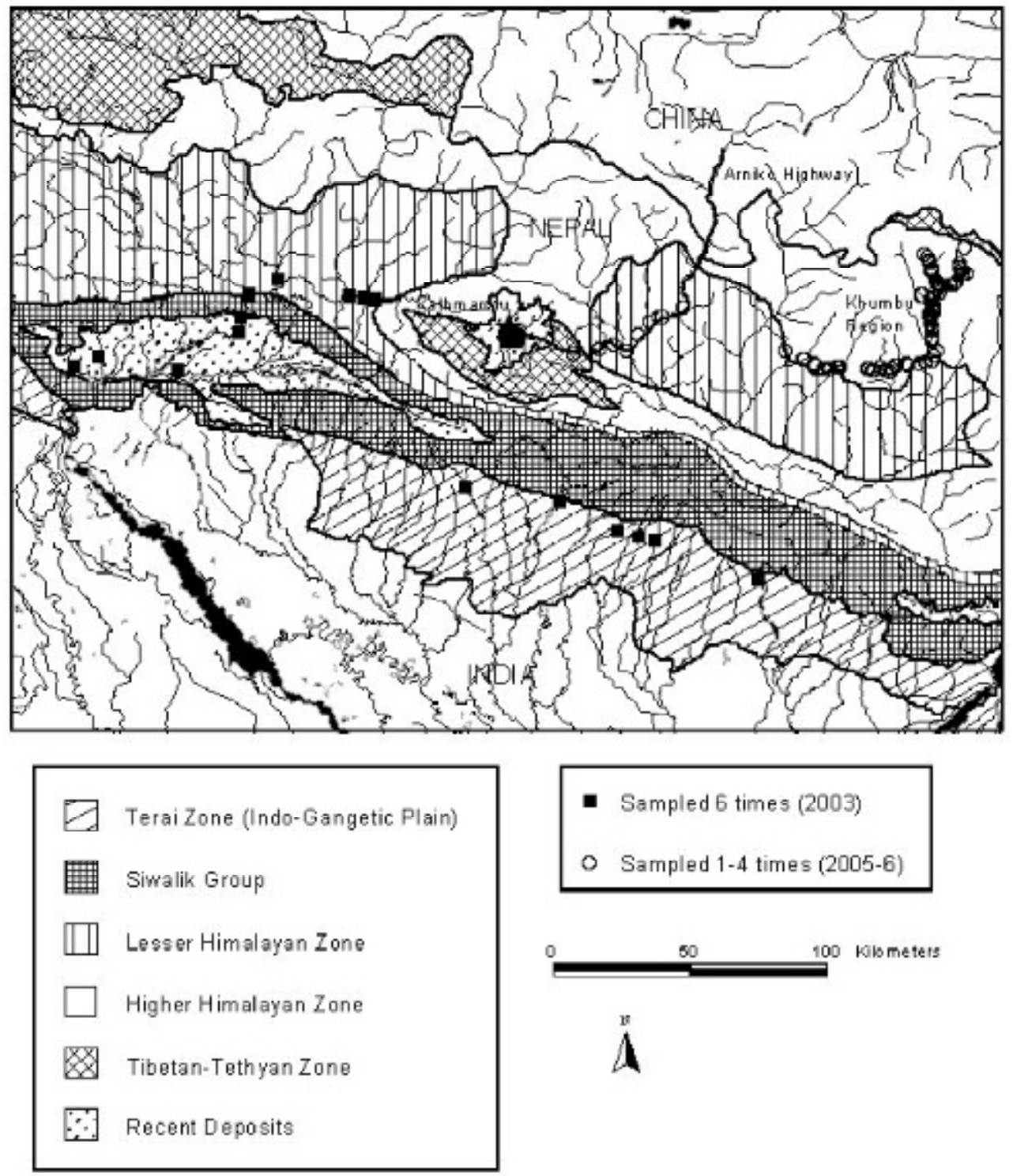

Fig. 1: Sampling sites superimposed on geological and drainage maps of Nepal. Geological map modified from Amatya and Jnawali (1994) and Dahal (2006). Drainage system based on Hearn et al. (2001). Geological zones are not extended into neighbouring countries. 

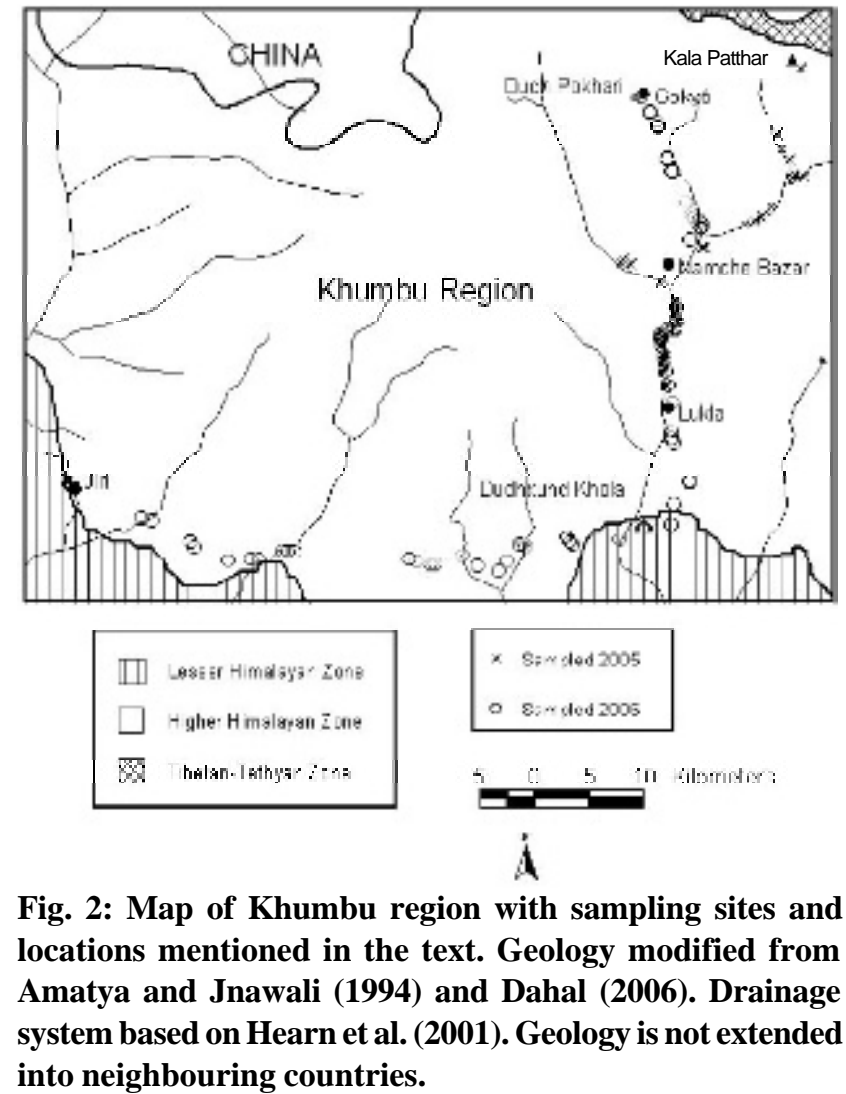

(5) Tibetan-Tethyan Zone, consisting largely of Palaeozoic to Mesozoic sedimentary rocks, and

(6) Recent Deposits.

Emerman (2005) did not sample any rivers dissecting rocks of the Higher Himalayan Zone. The objective of this study was to sample rivers dissecting the Higher Himalayan rocks of the Khumbu region (Figs. 1,2) in order to determine whether Higher Himalayan rocks are sources of As and other heavy metals. Related work on As and other heavy metals in rivers of other parts of south Asia was reviewed by Emerman (2005).

\section{MATERIALS AND METHODS}

River samples were collected from 30 sites along the trekking route from Lukla to Kala Patthar in the Khumbu region (Figs. 1, 2) during the period 31 May - 13 June 2005. At 21 sites, samples were collected during both the uphill and downhill treks for a total of 51 samples. River samples were also collected at 13 sites along the Arniko Highway (Fig. 1). River samples were again collected from the Khumbu region from 65 sites along the trekking route from Lukla to Gokyo to Jiri during the period May 12-28, 2006. At 24 sites, samples were collected during both the uphill and downhill treks for a total of 89 samples. The 2005 and 2006 treks sampled 11 of the same sites along the route between Lukla and Namche. Those 11 sites were also measured twice each year. In summary, this paper discusses the analyses of 153 samples collected in 2005 and 2006 in addition to the 150 samples collected in 2003 (Emerman 2005), for a total of 303 samples.

River samples were collected in 250-ml Nalgene bottles. The river $\mathrm{pH}$ was measured on-site with the Extech PH100 $\mathrm{pH}$ meter (precise to $0.01 \mathrm{pH}$ units). At each site, the $\mathrm{pH}$ was measured at least three times and was measured additional times until the readings were no longer monotonically increasing or decreasing. The median of all readings was accepted as the final measurement. The above method was found to give the highest reproducibility. The samples were not preserved, but were analysed for elemental concentrations the same day. Fe was measured with the Hach Total Iron FerroVer Method Pocket Colorimeter, $\mathrm{Cu}$ with the Hach Copper Pocket Colorimeter, Co and Ni with the Hach Nickel / Cobalt Pocket Colorimeter, Zn with the Hach DR-890 Portable Colorimeter, and As with the Hach Arsenic Test Kit. The Hach Arsenic Test Kit could be read reliably at 0, 5, 10, 20, 30, 40, 50, 60, and $70 \mathrm{mg} / \mathrm{l}$ The other instruments all had precision and minimum detection value of $10 \mathrm{mg} / \mathrm{l}$ Both Co and $\mathrm{Ni}$ were measured in 2005, but since $\mathrm{Co}$ and $\mathrm{Ni}$ were so well-correlated (results not shown), only Co was measured in 2006.

For data analysis, all sites were separated into six categories, which were (1) glacier-fed rivers sampled in the Khumbu region during 2005, (2) spring- and snowmelt-fed rivers sampled in the Khumbu region during 2005, (3) glacierfed rivers sampled in the Khumbu region during 2006, (4) spring- and snowmelt-fed rivers sampled in the Khumbu region during 2006, (5) rivers sampled in the Kathmandu valley during 2003, and (6) all other rivers. The first four categories were regarded as rivers dissecting rocks of the Higher Himalayan Zone. Although four sites from the Khumbu region were south of the Main Central Thrust (MCT) in the Lesser Himalayan Zone (Fig. 2), these sites were <1 $\mathrm{km}$ south of the MCT. Since the rivers flowed from the north out of the Higher Himalayan Zone, the elemental concentrations were regarded as due to leaching out of Higher Himalayan rocks. Sites measured in the Lesser Himalayan Zone along the Arniko Highway in 2005 (Fig. 1) were put into the last category of all other rivers. This category also included all rivers sampled outside of Kathmandu in 2003 (Fig. 1) so that rivers in this category dissected the Lesser Himalayan Zone, the Siwalik Group, the Terai Zone, and Recent Deposits (Fig. 1). The single site along the Arniko Highway in the Tibetan-Tethyan Zone was not included in any categories (Fig. 1).

Glacier-fed rivers were identified from trekking maps (MapPoint undated; Nepa Maps undated; Sherpa Maps undated) and the characteristic milky gray appearance of glacial meltwater. The two criteria were consistent with two exceptions. For each exception, the river was classified based on its appearance. According to a trekking map (Nepa Maps undated), Dudhkund Khola (Fig. 2) flows out of the Dudhkund Glacier, but it lacks the appearance of glacial 
meltwater. The most likely explanation is that Dudhkund Glacier no longer exists. Dudh Pokhari (Nepali for "Milk Lake," implying a glacial origin) (Map Point undated) was classified as spring- and snowmelt-fed as it had the blue colour of snowmelt (Fig. 2).

Arithmetic means of elemental concentrations and $\mathrm{pH}$ of the six categories were compared with one another and global averages (Drever 1997). Other workers (e.g., Lenvik et al. 1978; Salbu et al. 1979) have computed geometric means for fluvial chemical data under the assumption that geochemical data follow a lognormal distribution. However, recently Reimann and Filzmoser (2000) have criticised this assumption and argued that log-transformed data rarely are a better fit to a normal distribution than the untransformed data. Moreover, a logarithmic transformation requires an additional assumption about how to handle values that fall below the detection limit. A standard test for a normal distribution is that the cumulative frequency data should lie on a straight line when plotted against a probability scale (Reimann and Filzmoser 2000). The above test was applied to data in each of the above categories for $\mathrm{Fe}, \mathrm{Cu}, \mathrm{Co}, \mathrm{Zn}$, As and $\mathrm{pH}$ (results not shown). In no case was it found that log-transformed data more closely followed a normal distribution than untransformed data. Statistical significance was determined by $\mathrm{P}<0.05$ using the Student's unpaired t-test, which assume that data follow a normal distribution. Data from the 11 sites duplicated between 2005 and 2006 were compared using the Student's paired t-test. Data from the uphill and downhill treks for each year were also compared using the same test.

\section{RESULTS}

\section{Glacial meltwater and fluvial chemistry}

The most striking distinction among rivers in the Khumbu region was the difference between rivers fed primarily by glacial meltwater and those fed by springs and

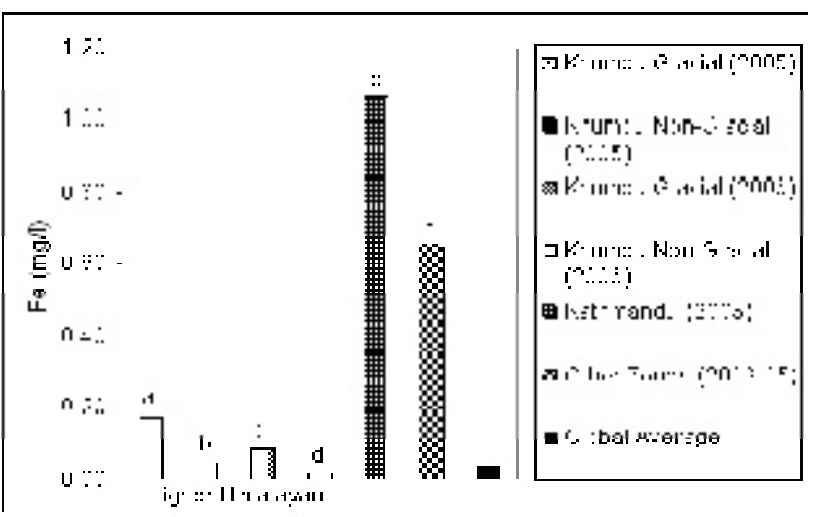

Fig. 3a: Comparison of fluvial Fe among Higher Himalayan Zone, other zones and global average (Drever 1997). Differences between columns that share a letter are not statistically significant at the $95 \%$ confidence level according to the Student's unpaired t-test. snowmelt. Glacial rivers had considerably more Fe and Co (Figs. 3a-b). The Fe concentration for non-glacial rivers differed little from the global average, while the Co concentration for even non-glacial rivers was about 150 times the global average (Figs. 3a-b). It is interesting that the Dudhkund Khola, which seemed to originate in the valley of a very recently vanished glacier, had the Fe-Co signature of a non-glacial river $(\mathrm{Fe}=0.08 \mathrm{mg} / \mathrm{l}, \mathrm{Co}=0.00 \mathrm{mg} / \mathrm{l})$. Similarly, Dudh Pokhari, which apparently until recently was fed by the rapidly retreating Ngozumpa Glacier had the Fe-Co signature of a non-glacial river $(\mathrm{Fe}=0.00 \mathrm{mg} / \mathrm{l}, \mathrm{Co}=0.00$ $\mathrm{mg} / \mathrm{l})$. Glacial and non-glacial rivers did not differ significantly in their $\mathrm{Cu}, \mathrm{Zn}$ or As concentrations, or in their pH (Figs. 3c-f). For both glacial and non-glacial rivers, $\mathrm{Cu}$ concentrations were considerably elevated above the global average (Fig. 3c).

\section{Geological zones and fluvial chemistry}

There was significantly greater $\mathrm{Fe}$ and $\mathrm{As}$ in rivers outside of the Higher Himalayan Zone (Figs. 3a, e). For both glacial and non-glacial rivers in the Khumbu region, As concentrations were indistinguishable from the global background level (Fig. 3e). Outside of Kathmandu and the Khumbu region, $53 \%$ of all river samples met or exceeded the WHO As standard of $10 \mu \mathrm{g} / \mathrm{l}$. In the Khumbu region, $<1 \%$ of samples had As concentration $\geq 10 \mu \mathrm{g} / \mathrm{l}$. Co concentrations outside of the Higher Himalayan Zone were similar to glacial rivers of the Khumbu region and much higher than non-glacial rivers (Fig. 3b). Fluvial $\mathrm{Cu}$ did not differ significantly among zones and seems to be elevated across a wide region of Nepal (Fig. 3c). It is difficult to evaluate the variation in fluvial $\mathrm{Zn}$ concentration among the geological zones due to the high annual variability in $\mathrm{Zn}$ concentration in the Khumbu region (Fig. 3d and further discussion below). The fluvial $\mathrm{pH}$ outside of the Higher Himalayan Zone is much higher than inside due to the relative lack of carbonate rocks within the Higher Himalayan Zone.

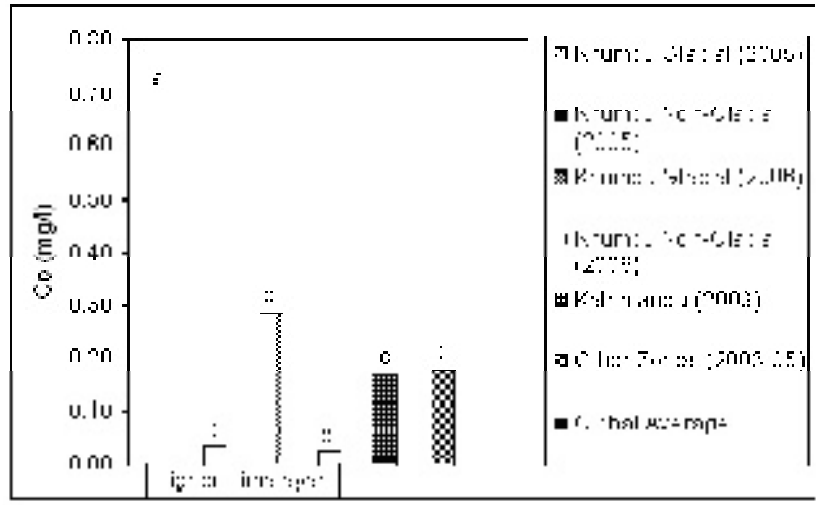

Fig. 3b: Comparison of fluvial Co among Higher Himalayan Zone, other zones and global average (Drever 1997). The global average $(0.0002 \mathrm{mg} / \mathrm{l})$ is not visible on the scale of this graph. Differences between columns that share a letter are not statistically significant at the $95 \%$ confidence level according to the Student's unpaired t-test. 


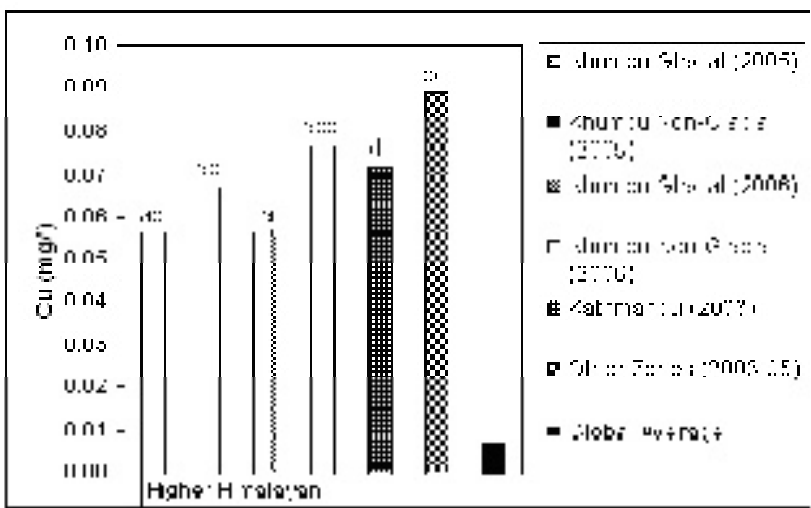

Fig. 3c: Comparison of fluvial $\mathrm{Cu}$ among Higher Himalayan Zone, other zones and global average (Drever 1997). Differences between columns that share a letter are not statistically significant at the $95 \%$ confidence level according to the Student's unpaired t-test.

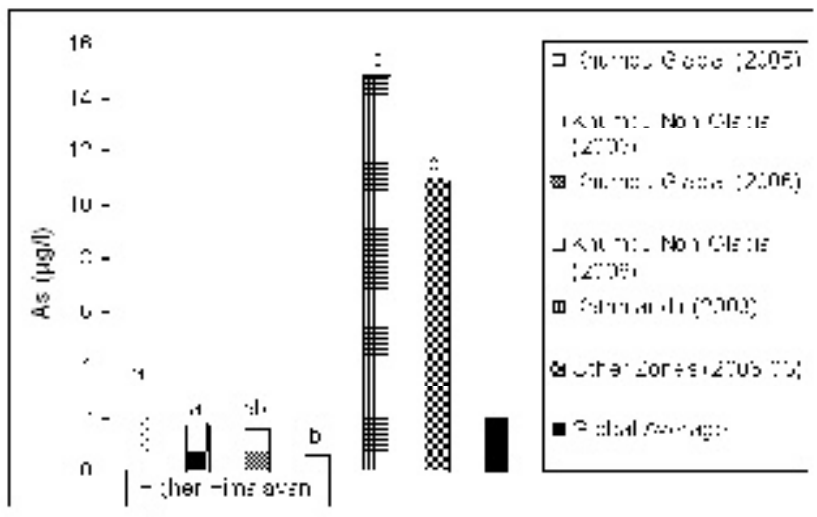

Fig. 3e: Comparison of fluvial As among Higher Himalayan Zone, other zones and global average (Drever 1997). Differences between columns that share a letter are not statistically significant at the $95 \%$ confidence level according to the Student's unpaired t-test.

\section{Annual variation in fluvial chemistry}

A surprising feature of this study was the pronounced annual variation in some fluvial heavy metals. Comparison of the 11 sites sampled in both 2005 and 2006 showed that $\mathrm{Fe}$ and $\mathrm{Zn}$ were significantly lower in 2006, while $\mathrm{Cu}$ was significantly higher (Table 1 ). Both $\mathrm{Fe}$ and $\mathrm{Zn}$ were reduced to global background levels $(\mathrm{Fe}=0.04 \mathrm{mg} / \mathrm{l}, \mathrm{Zn}=0.03 \mathrm{mg} / \mathrm{l})$ (Drever 1997) in the second year of study (Table 1). There was no annual variation in $\mathrm{Co}, \mathrm{As}$ or $\mathrm{pH}$ (Table 1). These same 11 sites were also sampled twice each year, within 1113 days in 2005 and within 8-10 days in 2006. Comparison of the two sets of measurements for each year makes it possible to distinguish between true annual variation and weekly variation that is sampled only annually. The only element that varied on a weekly basis was $\mathrm{Cu}$ (Table 2). In summary, rivers in the Khumbu region showed significant intermediate-

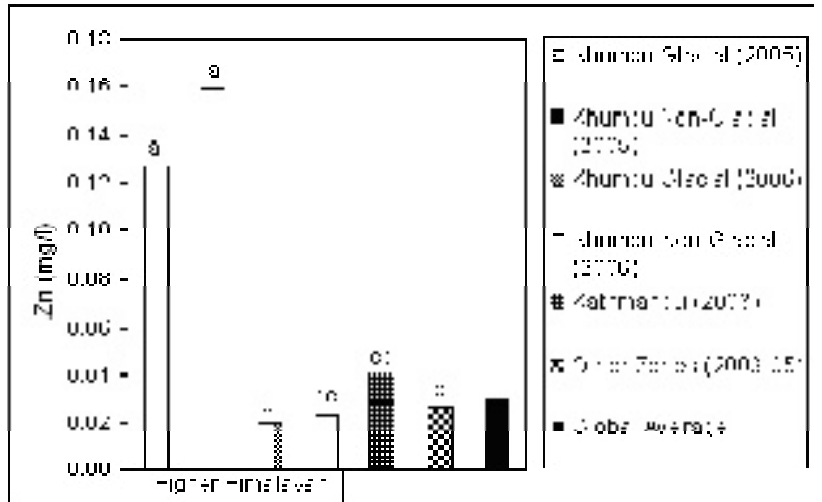

Fig. 3d: Comparison of fluvial $\mathrm{Zn}$ among Higher Himalayan Zone, other zones and global average (Drever 1997). Differences between columns that share a letter are not statistically significant at the $95 \%$ confidence level according to the Student's unpaired t-test.

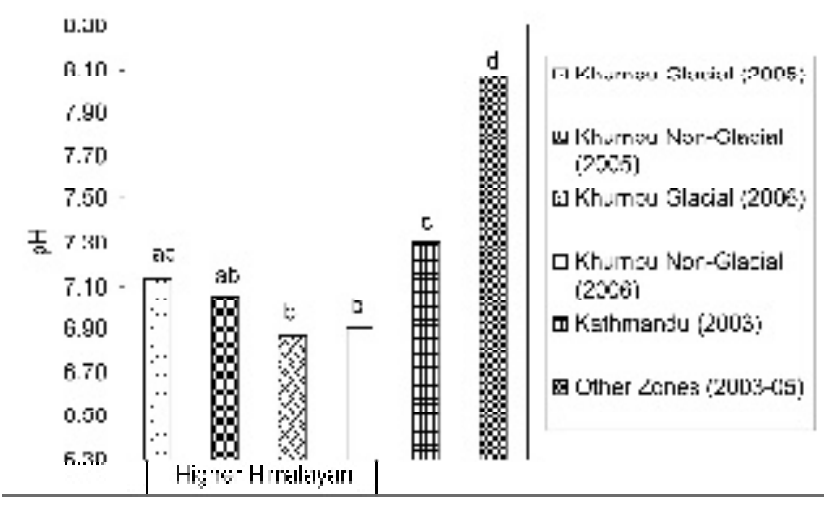

Fig. 3f: Comparison of fluvial pH among Higher Himalayan Zone and other zones. Differences between columns that share a letter are not statistically significant at the $95 \%$ confidence level according to the Student's unpaired t-test.

term (annual) variation in $\mathrm{Fe}$ and $\mathrm{Zn}$, significant short-term (weekly) variation in $\mathrm{Cu}$, and no temporal variation in $\mathrm{Co}$ and As.

Although fluvial pH did not vary between 2005 and 2006, $\mathrm{pH}$ decreased between the first and second sets of measurements for both years (Table 2). If all duplicate sites for a given year are taken into consideration, the second measurement of pH was always lower in 2005 (Fig. 4a). The second measurement was higher in 2006 only when the time between measurements was three days or less (Fig. 4b). The correlation between change in $\mathrm{pH}$ and time between measurements was not good enough for fluvial $\mathrm{pH}$ to be corrected for date of measurement. The decrease in fluvial $\mathrm{pH}$ with time probably results from the increasing proportion of snowmelt and precipitation to spring flow and glacial 
Table 1: Comparison of $\mathrm{pH}$ and $\mathrm{Fe}, \mathrm{Co}, \mathrm{Cu}, \mathrm{Zn}$ and $\mathrm{As}$ concentrations for rivers sampled at duplicate sites (11 sites sampled twice each year) in the Khumbu region for 2005 and 2006.

\begin{tabular}{c|c|c}
\hline Attribute & $\mathbf{2 0 0 5}$ & $\mathbf{2 0 0 6}$ \\
\hline $\mathrm{Fe}(\mathrm{mg} / \mathrm{l})$ & $0.10 \pm 0.03^{\mathrm{a}}$ & $0.05 \pm 0.01^{*}$ \\
\hline $\mathrm{Co}(\mathrm{mg} / \mathrm{l})$ & $0.3 \pm 0.1$ & $0.12 \pm 0.04$ \\
\hline $\mathrm{Cu}(\mathrm{mg} / \mathrm{l})$ & $0.05 \pm 0.01$ & $0.09 \pm 0.01^{* * *}$ \\
\hline $\mathrm{Zn}(\mathrm{mg} / \mathrm{l})$ & $0.14 \pm 0.02$ & $0.02 \pm 0.01^{* * *}$ \\
\hline $\mathrm{As}(\mu \mathrm{g} / \mathrm{l})$ & $0 \pm 5$ & $0 \pm 5$ \\
\hline $\mathrm{pH}$ & $6.85 \pm 0.07$ & $6.86 \pm 0.01$ \\
\hline
\end{tabular}

${ }^{a}$ Value \pm maximum of standard error and instrument precision, *, **, *** indicates difference between value for 2005 and 2006 is statistically significant at the 95\%, 99\%, 99.9\% confidence levels, according to the Student's paired t-test

meltwater in river discharge from the beginning to end of each trek.

\section{DISCUSSION}

\section{Source of Fe and Co in the Tibetan-Tethyan Zone}

The characteristic Fe-Co signature of rivers fed by glacial meltwater implies that glaciers are incorporating rock high in $\mathrm{Fe}-\mathrm{Co}$ that is not available in the rest of the Khumbu region. Quite possibly, glaciers in the Khumbu region are incorporating rock enriched in Fe-Co from the TibetanTethyan Zone (Figs. 1, 2). There are no mapped deposits of $\mathrm{Fe}$ or $\mathrm{Co}$ in this region of Nepal. In general, the very high levels of fluvial Co throughout Nepal cannot be accounted for by the known deposits of Co ores (Sharma 1995).

\section{Origin of fluvial As in Nepal}

The chief result of this study is that fluvial As does not originate in rocks of the Higher Himalayan zone. There is a possibility that As is not present in Higher Himalayan rivers in aqueous form, but exists as fluvial sediment. This sediment may eventually be deposited in the Terai Zone, where it may contribute to As contamination of groundwater. We believe this possibility to be unlikely. If As is present in fluvial sediment, it exists either in crystalline form or as oxyanions adsorbed onto clay minerals or Fe oxides. It is probably not present in crystalline form because most crystalline As is not a pure sulphide such as realgar $(\mathrm{AsS})$ or orpiment $\left(\mathrm{As}_{2} \mathrm{~S}_{3}\right)$, but is co-precipitated with a sulphide of $\mathrm{Fe}, \mathrm{Cu}, \mathrm{Co}$, Ni or $\mathrm{Zn}$, such as chalcopyrite $\left(\mathrm{CuFeS}_{2}\right)$ or sphalerite $(\mathrm{ZnS})$ (Smedley and Kinniburgh 2002). If crystalline As were present, it is unlikely that aqueous As would be so consistently missing in Khumbu rivers, while all of the above elements are, at least occasionally, abundant.

If As oxyanions were adsorbed onto sediment, there should be a positive correlation between $\mathrm{pH}$ and aqueous As (Emerman 2005). Such a correlation could not be found with such low levels of As concentration. However, a wide variety of attempts to correlate $\mathrm{pH}$ with any of the measured

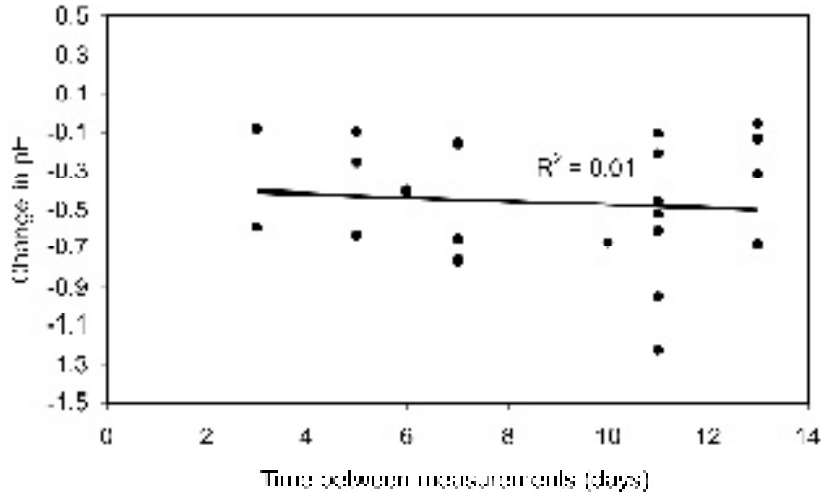

Fig. 4a: Change in $\mathrm{pH}$ with time at duplicate sites measured in the Khumbu region in 2005.

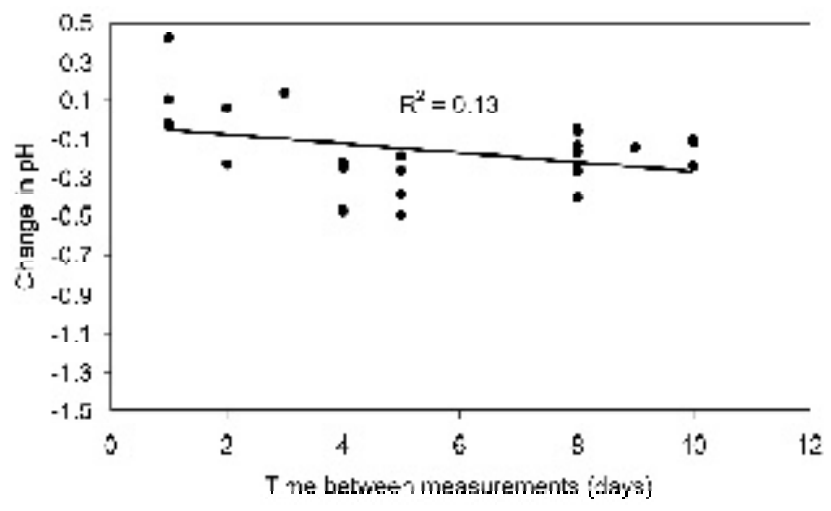

Fig. 4b: Change in pH with time at duplicate sites measured in the Khumbu region in 2006.

elements or combinations of elements were uniformly unsuccessful for data from the Khumbu region. This contrasted with data from Kathmandu and central Nepal, for which both As and the sum of measured cations $(\mathrm{Fe}+\mathrm{Co}+$ $\mathrm{Ni}+\mathrm{Cu}+\mathrm{Zn}$ ) were well-correlated with fluvial $\mathrm{pH}$ (Emerman 2005). The distinction is probably due to the lack of clays and Fe oxides in rivers of the Khumbu region, which is consistent with the short distance to the sources of sediment and the low rate of chemical weathering in the cold climate of the Khumbu region. The above conclusions could be tested by chemical and mineralogical studies of fluvial sediment in the Khumbu region.

The conclusion that fluvial As does not originate in Higher Himalayan rocks is consistent with the low As concentrations typically found in high-grade metamorphic rocks (Table 3). In fact, schists and gneisses have typical As concentrations among the lowest found in all rocks and sediments (Smedley and Kinniburgh 2002). It is important to note that the data in Table 3 do not include measurements made in any rocks from Nepal. Such measurements could, of course, help to test the conclusions of this study.

\section{Implications for groundwater As in the Terai Zone}

A variety of models have been proposed for the origin of groundwater As in south Asia, some of which have laid blame 
Table 2: Comparison of $\mathrm{pH}$ and $\mathrm{Fe}, \mathrm{Cu}, \mathrm{Co}, \mathrm{Zn}$ and As concentrations for first and second sets of measurements at identical sites for the 11 sites that were sampled in both 2005 and 2006.

\begin{tabular}{c|c|c|c|c}
\hline \multirow{2}{*}{ Attribute } & \multicolumn{2}{|c|}{$\mathbf{2 0 0 5}$} & \multicolumn{2}{c}{$\mathbf{2 0 0 6}$} \\
\cline { 2 - 4 } & First Set & Second Set 11-13 days later & First Set & Second Set 8-10 days later \\
\hline $\mathrm{Fe}(\mathrm{mg} / \mathrm{l})$ & $0.10 \pm 0.03$ & $0.10 \pm 0.02$ & $0.04 \pm 0.02$ & $0.04 \pm 0.01$ \\
\hline $\mathrm{Co}(\mathrm{mg} / \mathrm{l})$ & $0.3 \pm 0.1$ & $0.24 \pm 0.09$ & $0.16 \pm 0.06$ & $0.08 \pm 0.03$ \\
\hline $\mathrm{Cu}(\mathrm{mg} / \mathrm{l})$ & $0.05 \pm 0.01$ & $0.06 \pm 0.01$ & $0.12 \pm 0.02$ & $0.06 \pm 0.01 *$ \\
\hline $\mathrm{Zn}(\mathrm{mg} / \mathrm{l})$ & $0.12 \pm 0.02$ & $0.16 \pm 0.03$ & $0.02 \pm 0.01$ & $0.02 \pm 0.01$ \\
\hline $\mathrm{As}(\mu \mathrm{g} / \mathrm{l})$ & $0 \pm 5$ & $0 \pm 5$ & $0 \pm 5$ & $0 \pm 5$ \\
\hline $\mathrm{pH}$ & $7.1 \pm 0.1$ & $6.61 \pm 0.06^{* *}$ & $6.96 \pm 0.02$ & $6.78 \pm 0.02 * * *$ \\
\hline
\end{tabular}

${ }^{a}$ Value \pm maximum of standard error and instrument precision, *,**,*** indicates difference between value for first set and second set of measurements in a given year is statistically significant at the 95\%, 99\%, 99.9\% confidence levels, according to the Student's paired t-test

Table 3: Typical As concentrations in dominant rocks and sediments associated with the geological zones of Nepal. Data from Smedley and Kinniburgh (2002) do not include any measurements made on rocks from Nepal.

\begin{tabular}{c|c|c}
\hline Geological Zone & $\begin{array}{c}\text { Dominant } \\
\text { Rock/sediment }\end{array}$ & $\begin{array}{c}\text { As concentration } \\
\left(\mathbf{m g ~ k g}^{-1}\right)\end{array}$ \\
\hline Higher Himalayan Zone & Schist/gneiss & $1.1(<0.1-18.5)^{\mathrm{a}}$ \\
\hline \multirow{2}{*}{ Lesser Himalayan Zone } & Phyllite/slate & $18(0.5-143)$ \\
\cline { 2 - 3 } & $\begin{array}{c}\text { Limestone/ } \\
\text { dolomite }\end{array}$ & $2.6(0.1-20.1)$ \\
\hline Siwalik Group & Sandstone & $4.1(0.6-120)$ \\
\hline $\begin{array}{c}\text { Terai Zone, Recent } \\
\text { Deposits }\end{array}$ & $\begin{array}{c}\text { Various } \\
\text { sediments }\end{array}$ & $3(0.6-50)$ \\
\hline
\end{tabular}

${ }^{a}$ Average with range in parentheses

on specific human activities. Badal et al. (1996) and Mallick and Rajgopal (1996) have argued that over-pumping of aquifers has caused oxidation of sulfide minerals and release of co-precipitated As into groundwater. Acharyya et al. (1999, 2000) have proposed that excessive use of phosphate fertilisers has resulted in displacement of As from sediment adsorption sites by phosphate. Emerman (2004) has suggested that widespread deforestation has caused the loss of the soil microbial population that maintains soil As in an immobile, organic form. By contrast, most recent studies have argued that As contamination is unrelated to human activities. According to these studies, As contamination results from the release of As from adsorption sites on $\mathrm{Fe}$ oxyhydroxides after dissolution of the Fe oxyhydroxides (Nickson et al. 2000; McArthur et al. 2001; Bose and Sharma 2002; Harvey et al. 2002) or after reduction of adsorbed As from $\mathrm{As}^{+5}$ (arsenate) to $\mathrm{As}^{+3}$ (arsenite) (Bose and Sharma 2002). Both processes are likely under the strongly reducing conditions found in the thick package of alluvial sediments in West Bengal, Bangladesh, and Nepal (Bose and Sharma 2002). An alternative model is that As is displaced from adsorption sites by carbonate after sediments deposited in surface waters with low carbonate concentration are later exposed to groundwater with high carbonate concentration (Appelo et al. 2002). Still another alternative is that As is coprecipitated with diagenetic carbonate concretions and that As is released into groundwater upon dissolution of the carbonate concretions under acidic conditions (Shanker et al. 2001).
What all of the above models have in common is that they place emphasis on the particular environmental conditions that might cause As at concentrations normally present in soil or sediment to be released from soil or sediment into groundwater. None of the models assign any relevance to the particular concentration of soil or sediment As or to the As concentration of rivers draining into the affected area. We do not believe it is a coincidence that rivers in the Lesser Himalayan Zone, Siwalik Group, Terai Zone and Recent Deposits, all of which drain into the Terai Zone, have elevated levels of As. From this standpoint, something is missing from all the models under current consideration. One possibility is that, while all of the proposed mechanisms are thermodynamically plausible, the kinetics of each mechanism is poorly understood and may be too slow to be significant. If the kinetics is sufficiently slow, the groundwater chemistry is simply a reflection of the surface water chemistry. A partial test of this idea would be to measure groundwater $\mathrm{Co}, \mathrm{Ni}$, and $\mathrm{Cu}$ in the Terai, which should be very high based on the data in this study. There are currently no published measurements of heavy metals in groundwater in Nepal aside from $\mathrm{Fe}$ and As.

\section{ACKNOWLEDGEMENTS}

This work was partially funded by a Fulbright Alumni Initiative Award given to Simpson College and Tribhuvan University for "Cooperative Environmental Research between American and Nepali Undergraduate Students." We are grateful to Mr. Michael Gill and Dr. Peter Moran, former and current Executive Directors of USEF (United States Educational Foundation) Nepal, for their support.

\section{REFERENCES}

Acharyya, S. K., Chakraborty, P., Lahiri, S., Raymahashay, B. C., Guha, S. and Bhowmik, A., 1999, Arsenic poisoning in the Ganges delta. Nature, v. 401, p. 545.

Acharyya, S. K., Lahiri, S., Raymahashay, B. C. and Bhowmik, A., 2000, Arsenic toxicity of groundwater in parts of the Bengal basin in India and Bangladesh: The role of Quaternary stratigraphy and Holocene sea-level fluctuation. Environ. Geol., v. 39, pp. 1127-1137.

Amatya, K. M. and Jnawali, B. M., 1994, Geological Map of Nepal. Department of Mines and Geology, Ministry of Industry, Commerce and Supplies, Kathmandu, Nepal. 
Appelo, M., Van der Weiden, M. J. J., Tournassat, C. and Charlet, L., 2002, Surface complexation of ferrous iron and carbonate on ferrihydrite and the mobilisation of arsenic. Environ. Sci. Technol., v. 36, pp. 3096-3103.

Aswathanarayana, U., 1997, Arsenic in groundwater, West Bengal. Jour. Geol. Soc. India, v. 49, pp. 341-345.

Badal, K. M., Roy Choudhury, T., Samanta, G., Basu, G. K., Chowdhury, P. P., Chanda, C. R., Lodh, D., Karan, N. K., Dhar, R. K., Tamili, D. K., Das, D., Saha, K. C., and Chakraborti, D., 1996, Arsenic in groundwater in seven districts of West Bengal, India - The biggest As calamity in the world. Current Sci., v. 70, pp. 976-985.

Bhattacharya, P., Chatterjee, D., and Jacks, G., 1997, Occurrence of As-contaminated groundwater in alluvial aquifers from the Delta Plains, Eastern India: Options for safe drinking water supply. Water Resour. Dev., v. 13, pp. 79-92.

Bhattacharya, P., Tandukar, N., Neku, A., Valero, A. A., Mukherjee, A. B., and Jacks, G., 2003, Geogenic arsenic in groundwaters from Terai Alluvial Plain of Nepal. Jour. Phys. IV France, v. 107, pp. 173-176.

Bhattacharyya, B. P., 1972, Arsenic mineralization in parts of Hazaribagh District, Bihar. Indian Min., v. 26, pp. 28-34.

Bose, P. and Sharma, A., 2002, Role of iron in controlling speciation and mobilization of arsenic in subsurface environment. Water Res., v. 36, pp. 4916-4926.

Boyle, R. W. and Jonasson, I. R., 1973, The geochemistry of arsenic and its use as an indicator element in geochemical prospecting. Jour. Geochem. Explor., v. 2, pp. 251-296.

Brikowski, T. H., Smith, L. S., Shei, T.-C., and Shrestha, S. D., 2004, Correlation of electrical resistivity and groundwater arsenic concentration, Nawalparasi, Nepal. Jour. Nepal Geol. Soc., v. 30, pp. 99-106.

Dahal, R. K., 2006, Geology for Technical Students. Bikruti Academic Publications, Kathmandu, Nepal, 746 p.

Das, S., 1977, A note on prospecting of Amjhore pyrite, Rohtas district, Bihar with discussion on the origin of the deposits. Indian Min., v. 31, pp. 8-23.

Dhar, R. K., Biswas, B. K., Samanta, G., Mandal, B. K., Chakraborti, D., Roy, S., Jafar, A., Islam, A., Ara, G., Kabir, S., Khan, A. W., Ahmed, S. K., and Hadi, S. A., 1997, Groundwater As calamity in Bangladesh. Current Sci., v. 73, pp. 48-59.

Drever, J. I., 1997, Geochemistry of Natural Waters: Surface and Groundwater Environments, $3{ }^{\text {rd }}$ ed. Prentice Hall, Upper Saddle River, New Jersey, 436 p.

Emerman, S. H., 2004, Deforestation, arsenic, and the selforganizing jungle in the Terai region of Nepal. Jour. Nepal Geol. Soc., v. 29, pp. 13-22.

Emerman, S. H., 2005, Arsenic and other heavy metals in the rivers of central Nepal. Jour. Nepal Geol. Soc., v. 31, pp. 11-18.

Environment and Public Health Organization (ENPHO) and United States Geological Survey (USGS), 2004, The state of arsenic 2003 in Nepal (a draft report). National Arsenic Steering Committee (NASC), Kathmandu, Nepal, 102 p.

Ghosh, S. and De, S., 1995, Source of the arsenious sediments at Kachua and Itina, Habra Block, North 24 Parganas, West Bengal - A case study. Indian Jour. Earth Sci., v. 22, pp. 183-189.

Harvey, C. F., Swartz, C. H., Badruzzaman, A. B. M., KeonBlute, N., Yu, W., Ali, M. A., Jay, J., Beckie, R., Niedan, V., Brabander, D., Oates, P. M., Ashfaque, K. N., Islam, S., Hemond, H., and Ahmed, M.F., 2002, Arsenic mobility and groundwater extraction in Bangladesh. Science, v. 298, pp. $1602-1606$
Hearn, P., Hare, T., Schruben, P., Sherrill, D., LaMar, C., and Tsushima, P., 2001, Global GIS Database: Digital Atlas of South Asia. U.S. Geological Survey Digital Data Series DDS-62-C.

Kanel, S. R., Choi, H., Kim, K. W., and Moon, S. H., 2005, Arsenic contamination in groundwater in Nepal: a new perspective and more health threat in South Asia, In: Bundschuh, J., Bhattacharya, P., and Chandrasekharam, D. (Eds.) Natural Arsenic in Groundwater: Occurrence, Remediation and Management, A.A. Balkema Publishers, Leiden, pp. 103-108.

Lenvik, K., Steinnes, E., and Pappas, A. C., 1978, Contents of some heavy metals in Norwegian rivers. Nord. Hydrol., v. 9, pp. 197-206.

Mallick, S. and Rajgopal, N. R., 1996, Groundwater development in the arsenic-affected alluvial belt of West Bengal - some questions. Current Sci., v. 70, pp. 956-958.

Map Point, undated, Gokyo: The Six Sacred Lakes.

McArthur, J. M., Ravenscroft, P., Safiullah, S. and Thirlwall, and M. F., 2001, Arsenic in groundwater: Testing pollution mechanisms for sedimentary aquifers in Bangladesh. Water Resour. Res., v. 37, pp. 109-117.

Neku, A. and Tandukar, N., 2002, A report on arsenic programme (Mitigation measures and a training manual). Department of Water Supply and Sewerage, Ministry of Physical Planning and Works, Kathmandu, Nepal, 53 p.

Nepa Maps, undated, Khumbu: Jiri to Everest. Himalayan MapHouse, Kathmandu, Nepal.

Nickson, R. T., McArthur, J. M., Burgess, W. G., Ahmed, K. M., Ravenscroft, P., and Rahman, M., 1998, Arsenic poisoning of Bangladesh groundwater. Nature, v. 395, 338 p.

Nickson, R. T., McArthur, J. M., Ravenscroft, P., Burgess, W. G., and Ahmed, K. M., 2000, Mechanism of arsenic release to groundwater, Bangladesh and West Bengal. Appl. Geochem., v. 15 , pp. 403-413.

Reimann, C. and Filzmoser, P., 2000, Normal and lognormal data distribution in geochemistry: Death of a myth. Consequences for the statistical treatment of geochemical and environmental data. Environ. Geol., v. 39, pp. 1001-1014.

Salbu, B., Pappas, A. C., and Steinnes, A. C., 1979, Elemental composition of Norwegian rivers. Nord. Hydrol., v. 10, pp. 115-140.

Shanker, R., Pal, T., Mukherjee, P. K., Shome, S, and Sengupta, S., 2001, Association of microbes with arsenic-bearing siderite concretions from shallow aquifer sediments of Bengal delta and its implication. Jour. Geol. Soc. India, v. 58, pp. 269-271.

Sharma, C. K., 1995, Mineral Resources of Nepal. Mrs. Sangeeta Sharma, Kathmandu, Nepal, 142 p.

Sherpa Maps, undated, Lukla to Everest Base Camp.

Shrestha, S. D., Brikowski, T., Smith, L., and Shei, T.-C., 2004, Grain size constraints on arsenic concentration in shallow wells of Nawalparasi, Nepal. Jour. Nepal Geol. Soc., v. 30, pp. 93-98.

Smedley, P. L. and Kinniburgh, D. G., 2002, A review of the source, behaviour and distribution of arsenic in natural waters. Appl. Geochem., v. 17, pp. 517-568.

Stöcklin, J., 1980, Geology of Nepal and its regional frame. Jour. Geol. Soc. London, v. 137, pp. 1-34.

Tandukar, N., Bhattacharya, P., Jacks, G., and Valero, A.A., 2005 , Naturally occurring arsenic in groundwater of Terai region in Nepal and mitigation options, In: Bundschuh, J., Bhattacharya, P., and Chandrasekharam, D. (Eds.) Natural Arsenic in Groundwater: Occurrence, Remediation and Management, A.A. Balkema Publishers, Leiden, pp. 41-48. 